\title{
Managing Dental Patient with Auditory Deficit: Literature Review
}

\author{
Fabiana C Martinez $H^{1^{*}}$, Frederick Segura $R^{2}$ and Jacqueline $C$ Herrera $M^{2}$ \\ ${ }^{1}$ Honorem Hospital Rafael Zamora Arévalo, Gran Mariscal de Ayacucho University, Venezuela \\ ${ }^{2}$ National Experimental University Rómulo Gallegos, Venezuela
}

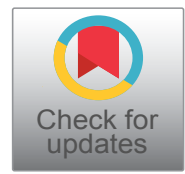

*Corresponding author: Fabiana C Martinez H, Dentist, Honorem Hospital Rafael Zamora Arévalo, Gran Mariscal de Ayacucho University, \#51, Real Street, Valle De La Pascua City, Guarico State, Venezuela, Tel: +58-414-3920000

\begin{abstract}
Summary
Introduction: Hearing is the usual way of acquiring language, which is one of the most important attributes of man. Language allows human beings to communicate with each other and has had a decisive participation in the development of society and its many cultures. Auditory deficit carries personal and social consequences, such as difficulties and/ or conflicts when receiving care from the doctor or dentist.
\end{abstract}

Objectives: The objective of this article is to describe the determinants of the patient with auditory deficit to take into account at the moment of his dental care and to establish the communication strategies for an effective relation to the patients with deficiencies Auditory in the dental consultation in order to develop a practical guide aimed at the dental professional for the care of patients with hearing impairments.

Materials and methods: A bibliographic review was carried out by means of the consultation of databases of the reference systems, such as SciElo and Google using the combinations of keywords: Deafness, auditory deficit, dental management among others. In addition, original printed texts were also available.

Development: Conventional methods of dental treatment are not modified by treating patients with functional diversity, only use a different management to establish a more effective dentist-patient relationship functional diversities Sensory (deafness and blindness) require the use of strategies to improve communication, using sign language, writing, use of Braille, lip reading and stimulating the sensopercepción of the patient's eyesight, touch and hearing.

Conclusion: A hearing impairment represents, for those who suffer, a barrier in communication with the rest of society, especially when receiving health care. The dentist must know and possess the necessary strategies and tools to cope with this situation and successfully achieve the proposed treatment objectives.

\section{Keywords}

Auditory deficit, Deafness, Dental management, Disability, Oral state, Caries, Communication, Oral manifestations

\section{Introduction}

The law for Persons with disabilities in Venezuela defines functional diversity as any complex condition of the human being constituted by biopsychosocial factors, which evidences a temporary or permanent reduction or suppression of any of its capacities sensory, motors or intellectual that may manifest in absences, anomalies, defects, losses or difficulties to perceive, to move without support, to see or to hear, to communicate with others, or to integrate with the activities of education or work, in the family with the Community, limiting the exercise of rights, social participation and the enjoyment of a good quality of life, or impeding the active participation of people in the activities of family and social life, without necessarily implying disability or Inability to insert socially [1].

Hearing is the usual way to acquire language, and the total or partial loss of this ability can alter the behavior of individuals. According to who "It is called hearing defect to the inability to hear as well as a person whose hearing is normal". More than $5 \%$ of the world's population ( 360 million people) suffer from disabling hearing loss ( 328 million adults and 32 million children). Disabling hearing loss means hearing loss greater than $40 \mathrm{~dB}$ (Decibel) in the ear with better hearing in adults, and superior to $30 \mathrm{~dB}$ in the ear with better hearing in children. Most people with disabling hearing loss live in low-and middle-income countries.

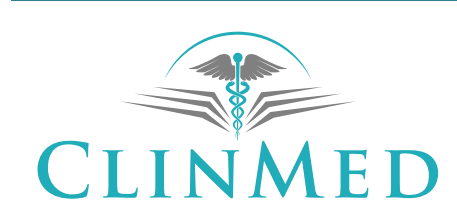

INTERNATIONAL LIBRARY 
In today's working world, the dental professional needs to develop strategies that lead to respond to less frequent stimuli of their environment. In health sciences, the dentist has the need to adapt to the treatment with people who have a functional diversity situation, who require care, medical management and use of assistance or specialized programs in health to provide a treatment specific to his condition.

\section{Materials and Methods}

A bibliographical review was carried out through the consultation of databases of the reference systems, such as SciELO and Google using the combinations of keywords: Deafness, auditory deficit, dental management among others. In addition to this search, the references selected from several original printed texts were included in the review.

\section{Literature Review}

Hearing loss is one of the most common chronic health problems, affecting people of all ages, in all segments of the population and at all socioeconomic levels. Hearing loss affects approximately 17 out of every 1000 children and young people under the age of 18. The incidence increases with age: Approximately 314 of every 1000 people over 65 -years-old suffers hearing loss. This may be hereditary or may be the result of illness, trauma, long-term exposure to noise, or medications. Hearing loss may vary from a mild, but significant decrease in hearing sensitivity to a total loss.

The International Classification of Diseases of the World Health Organization (WHO-2001) defines disability as the loss or limitation of opportunities in the normal life of the community on equal terms with others due to social and physical barriers [2]. WHO estimates that in 2001, 250 million people around the world had a hearing impairment (moderate or severe) [3]. Children with hearing impairments are one of the main groups in the child population with disabilities [4].

We define as capacity, according to criteria of the World Health Organization (WHO), the possibility of carrying out a certain activity in the form or range considered normal for the man.

Since we maintain that having a normal hearing capacity implies both hearing and listening, because the ability to hear (which is translated by a behavior called afferent auditory acuity or acuity), and depends for its functioning of peripheral hearing: Outer ear, middle ear and inner ear (up to the second neuronal station of the cochlear branch of the auditory pathway), when we do not hear correctly we are then facing a peripheral hearing impairment [5].

The personal and social consequences of hearing loss include, among others, difficulties and/or conflicts when it comes to receiving health care. An individual with special health care needs is one with a commit- ment or situation of physical or psychomotor, psychic or cognitive and sensory limitation and present varying degrees of involvement requiring intervention [6], medical management and use of Health care or specialized programs.

\section{Dental Considerations}

It is important that the health professional, especially the dentist, has good communication with the patient, that allows him to receive all the information possible about his physical, mental, social and environmental state [7], since there are many situations in the Which alterations in the oral cavity can affect the general health, for this reason, to the need to attend patients with hearing limitations is of vital importance to know the etiology and the consequences of this one, reason why it should be aware of The psychological effects of hearing impairment.

The clinical features of the oral cavity in this type of patients are similar to a large extent from the rest of the individuals; Hard tissue alterations include a higher prevalence of enamel hypoplasia and dental demineralization. A higher incidence of bruxism, especially when one is to another disability (deaf-mute), also appears during periods of inactivity and can serve to fill the sensory vacuum [8], the communication between the clinician and the patient is essential to be able to perform a Good diagnosis, being audition only part of the process; Through non-verbal communication, perception and acute powers of observation, effective levels can be achieved for the dental treatment of deaf patients [9].

Jain and collaborators [10] studied the oral state and the need for treatment of 127 deaf young patients. The most important finding of the study was the high prevalence of caries and poor oral hygiene. Knowing how to identify these oral characteristics serves the dentists to formulate the early and effective diagnosis to channel in a timely manner the treatment required by these patients [11].

\section{Oral Manifestations}

Access to the oral cavity can be difficult for many reasons. The acclimation and use of behavioral techniques can be useful to develop a good relationship and trust in order to achieve cooperation. Empathy along with practicality is usually the best way to overcome the challenge of providing dental care to these people [7].

The clinical characteristics of the oral cavity do not differ greatly from the rest of the individuals. Hard tissue alterations include a higher prevalence of enamel hypoplasia and dental demineralization related to prematurity and rubella, two common causes of deafness. The dental Wear (bruxism) during the vigil is common, many times, this habit appears during periods of inactivity and can serve to fill the sensory void left by the disability $[7,11]$. 
-Caries: Due to the lack of hygiene, the type of diet that these patients usually have and the lack of control visits to the dentist, tooth decay is usually the most prevalent pathology in the populations of patients with disabilities, mainly in the groups of Blind patients, deaf and cerebral palsy [12].

-Periodontal disease: Periodontal disease is a chronic and multifactorial infectious Pathology where a progressive destruction of the supporting tissues of the dental structures occurs. The development of periodontal disease is initially given by the presence of dental plaque, but there are factors of risk of type immunologic, hormonal and cellular that can lead to a faster or aggressive evolution. Patients who have some type of disability, have a greater predisposition to develop periodontal disease, mainly in some such as severe congenital neutropenia, genetic infantile a granulomatosis, Chediak-Higashi syndrome, Down syndrome and Papillon-Lefevre syndrome. In the rest of the disabilities also predisposed it is increased by the lack of hygiene in the patient [13].

-Malocclusions: There are several genetic determinations that favor the development of malocclusions in most patients with physical and psychic disabilities. In addition to this there are many habits such as oral respiration, digital suction and lingual interposition. Because of the lack of chewing, autistic patients usually have dental crowding, patients with infantile Cerebral palsy develop severe anterior open bites. On the other hand, children with Down syndrome present maxillary wide spaced hypoplastic, with the consequent decrease in the development of the palate, which is usually deep. The upper maxilla is usually smaller than the lower jaw, giving rise to certain malocclusions, the most common being the Angle class III, where the mandible is located in front of the upper jaw. In the second position are the class I bites of Angle, with crowding, anterior open bite or associated lateral cross; Being the class II occlusion the least common in them [14-16].

-Self-harm: These are acts of self-aggression that result in tissue damage. The percentages of patients with disabilities who have self-harm are between 7.7 and 22.8, without distinction of sex. Behaviors of aggression tend to manifest themselves in the context of developmental disorders such as mental retardation and autism; Psychiatric disorders such as obsessive-compulsive disorder, anorexia, schizophrenia and body dysmorphic disorder; Neurological disorders such as Tourette's syndrome, neuroacanthosis, and chronic pain syndrome. Several authors say that there is a significant association between the presence and severity of self-aggression behavior and the presence of poor cognitive abilities, repetitive abnormal behaviors such as estereotipias, movement disorders or of sleep. They may have a neurological, biological, or psychological origin, and the patient may be hit or bitten by any part of the body, mainly the hands, face, and jaw [17].

\section{Management of Deaf Patients}

San Bernardino and collaborators [18] proposed rules to improve communication with the patient who presents this functional diversity, these include knowing the form of communication that they use for their social development, whereas the different methods, how to use language of signs, written language, lip reading or mixture of any of these. It is important to know the behavior of the patient with auditory deficit, they should be made certain adjustments during the consultation [10], because communication with someone who are deaf or hard of hearing is fundamental and is not difficult. There are basic rules that can be followed for success in communication, as described by Dougall and associates [19] and available communication media that help:

1. Headset: Verify that the device is on. Often shuts off due to interference that may occur in close proximity to the professional and some dental equipment.

2. Lip reading: Must speak clearly at normal pace, with good articulation, facing the patient, allowing the reading of the lips.

3. The interpreter: Repeats what is said without the use of his voice, allowing you to easily read lips. They use natural gestures and facial expressions to help the person to follow what is said, also will draw on the formation of words with fingers $[8,19]$.

A study by Champion and collaborators [20] showed that it is useful that the dentist, while talking with the patient, remove is the top mouth to facilitate the use of signs, gestures and the interpretation of the lips that can improve communication with children deaf.

According to a study conducted by Garbin and collaborators [21], the most used communication method was the assistance of an interpreter being, in all cases, a close relative or a friend. However, the acompanante-interprete often does not transmit information to the patient. This fact attests to the deaf becomes oblivious to his own oral condition and, sometimes, even knows what are the measures that will be taken. It would be useful for the dentist who could learn, at least at a basic level, sign language, and some ideograms to greet the patient, receive it at the office, present with it and be able to explain what is the treatment that is going to perform, this being a basic strategy proposed by Madrigal and collaborators [10] in his study. Delve into the world of people with diverse hearing helps sensitized and give offers that these patients will know the office through your other senses.

Clinical management should be filled mostly with patience. The presence of a hearing impairment will be referred to in the medical record. Requested a consultation with the doctor treating where deafness-associated disorders, are reflected as well as their physical and psychological state [22]. 
Attention to the patient with auditory deficit in the dental clinic is a team work, they will be involved: the patient, the dentist, auxiliary and parents or close the patient's relatives.

For the first visit to the clinic, it is advisable to show him books and pamphlets that offered a realistic picture of this new situation. Modeling is also very useful, noting the good behavior of another patient in order to imitate it.

The dentist should explain everything that happens, since the deaf patient much afraid of the unknown. Usually you will find instruments and equipment, you will be informed of the vibrations, that due to the team will feel, warning him that they are normal. The sequence of work will always be show-say-do. During explanations, it is advisable to not wear masks, since they prevent them see our gestures, as well as read lips, denied most of the facial expressions. The body language and facial expressions play a very important role in communicating with the deaf patient [23].

Auxiliary not will call the patient by name, unless you approach it; It will lead you to the dental chair, placing the dentist, Assistant and the interpreter so that the patient can see them easily.

A caress or a handshake is a positive reinforcement for the patient, being for the deaf one important way of expressing pleasure to him or encourage him to go ahead with the treatment.

It is important to emphasize that the use of rubber in dental procedures dam can result in negative behavior if it prevents you from view, since it is the main form of communication by the patient, thus increasing isolation and anxiety.

It is of particular relevance that during their stay in the dental practice the deaf patient feel that members of health care team working calmly, are relaxed and you are treated with tact and amicably.

\section{Conclusion}

The dentist benefits from developing strategies to manage patients with functional diversity ensuring effective and effective consultation. Prevention is the main strategy for dealing with intellectual functional diversities. The dentist should use a different management in the relationship with patients with functional diversity without modifying conventional methods of dental treatment. All the strategies used in the management of patients with sensory functional diversities are aimed at establishing effective communication. It is advisable to delve into the most effective techniques based on scientific knowledge, to manage patients with functional diversity in the dental office.

\section{References}

1. LA Asamblea Nacional de la República Bolivariana de Venezuela. Ley para personas con discapacidad.
2. Griffiths J (2008) Defining disability and special care dentistry. Rev Dental Nursing 4: 190-194.

3. Ciger S, Akan S (2010) Occlusal characteristics of deaf-mute individuals in the Turkish population. Eur J Dent 4: 128-136.

4. Jain M, Mathur A, Kumar S, Dagli RJ, Duraiswamy $P$, et al. (2008) Dentition status and treatment needs among children with impaired hearing attending a special school for the deaf and mute in Udaipur, India. J of Oral Science 50: 161-165.

5. González J (2008) Alteraciones del Habla en la Infancia: Aspectos Clínicos. (1 ${ }^{\text {st }}$ edn), Reimp Buenos Aires: Editorial Médica Panamericana. 2: 18.

6. Silvestre F, Plaza A (2007) Odontología en pacientes especiales. Editorial Universidad de Valencia 11: 249.

7. Martínez H, Treviño M, Rivera G (2011) Guía para el cuidado de la salud oral en pacientes con necesidades de cuidados especiales de salud en México. Revista ADM 68: 222-228.

8. Dougall A, Fiske J (2008) Access to special care dentistry, part 2. Communication. Br Dent J 205: 11-21.

9. Alzamora Leslie, Bello Zaidy, Rodríguez Felicidad (2009) Diseño de protocolo de atención odontológica a pacientes del Instituto para la habilitación del niño sordo de cartagena de Indias. Ciencia y Salud Virtual 1: 62-68.

10. Cuenca S, Manau C (2002) Odontología preventiva y comunitaria. Principios métodos y aplicaciones. ( $3^{\text {rd }}$ edn).

11. Madrigal Gerardo Elías, Martínez Sandoval Beatriz Elena, De la Teja Ángeles Eduardo, Canto Cervera Diana Beatriz (2006) Manejo estomatológico del niño sordo o con hipoacusia. Rev Mex Odon Clín 1: 26-32.

12. De la Teja E, Durán A, Espinosa L, Ramírez, JA (2008) Manifestaciones estomatológicas de los trastornos sistémicos más frecuentes en el Instituto nacional de Pediatría. Revisión de la literatura y estadísticas del instituto. Acta Pediátrica de Méx 29: 189-199.

13. Pirela de Manzano A, Salazar CR, Manzano MA (1999) Patologia bucal prevalente en ninos excepcionales. Acta Odont Venez 37: 193-198.

14. Nualart Grollmus ZC, Morales Chavez MC, Silvestre Donat FJ (2007) Periodontal disease associated to systemic genetic disorders. Med Oral Patol Oral Cir Bucal 12: E211-E215.

15. Morales-Chavez MC (2008) Patologías bucodentales y alteraciones asociadas prevalentes en unapoblación de pacientes con parálisis cerebral infantil. Acta Odont Venez 46.

16. Jiménez MJ, López J, Alio JJ (1998) Limitaciones en el tratamiento de lasmaloclusiones en el Síndrome de down. Revista Iberoamericana de Ortodoncia 17: 59-65.

17. Jimenez J, Gimenez MJ, Gallifa E (1998) Características odonto-estomatológicas del niño con Síndrome de down. Rev Eur de Odontoestomatol 2: 103-110.

18. Lewis M, Bodfish J (1998) Repetitive behavior disorders in autism. MRDD Research Reviews 4: 80-89.

19. Alsmark SS, García J, Martínez MR, López NE (2007) How to improve communication with deaf children in the dental clinic. Med Oral Patol Oral Cir Bucal 12: e576-e581.

20. Dougall A, Fiske J (2008) Access to special care dentristy part 4. Education. Br Dent J 205: 119-130.

21. Champion J, Holt R (2000) Dental care for children and young people who have a hearing impairment. Br Dent $J$ 189: 155-159.

22. Garbin C, Garbin A, Sumida D, Prado R, Gonzaga L (2008) Evaluacion del tratamiento personal recibido porpacientes sordos en consultorio odontologico. Acta Odontologica de Venezuela 46.

23. Rios Y, Silot E (2016) Paciente Discapacitado. Normas para su atención en Odontologia. 